\title{
Treści (między)kulturowe w procesie kształcenia przedszkola i edukacji wczesnoszkolnej - na podstawie analizy aktualnych podstaw programowych
}

Streszczenie: Celem artykułu jest zaprezentowanie obowiązujących podstaw programowych przedszkola i edukacji wczesnoszkolnej w perspektywie problematyki dotyczącej różnorodności kulturowej. Znajomość własnego środowiska lokalnego i kanonu kulturowego regionu stanowi ważny element edukacji międzykulturowej. Stąd przeglądu podstaw dokonano przez pryzmat założeń zarówno edukacji regionalnej, jak i międzykulturowej. Przedstawione zostały ustanowione w podstawie zadania i cele, jakie stoją przed współczesnym przedszkolem i szkołą, ale i efekty kształcenia, za pomocą których określono w podstawie programowej treści przewidziane do realizacji w procesie uczenia się i nauczania. Teoretycznymi podstawami rozważań uczyniono koncepcję tożsamości międzykulturowej opracowaną przez Jerzego Nikitorowicza.

Słowa kluczowe: edukacja przedszkolna i wczesnoszkolna, podstawa programowa, efekty uczenia się, treści kształcenia, edukacja regionalna, edukacja międzykulturowa

\section{Wprowadzenie}

W niniejszym tekście podejmuję próbę refleksji nad zagadnieniem aktualnych założeń programowych z zakresu edukacji regionalnej i międzykulturowej. Punktem odniesienia czynię treści zawarte w założeniach, celach oraz efektach kształcenia najnowszej podstawy programowej obowiązującej w przedszkolu i na pierwszym etapie szkoły podstawowej - edukacji wczesnoszkolnej. Od wielu lat w naszym kraju podstawa jest postrzegana jako jeden z najbardziej kontrowersyjnych dokumentów określających treści kształcenia. Aktualny jej kształt przyjmuje w zasadzie wyłącznie zestaw zapisu efektów uczenia się, prezentowanych w postaci zachowań dzieci i uczniów na poszczególnych etapach edukacyjnych. Podstawa nie jest już - jak w przy- 
padku pierwszych jej wersji - kanonem treści, które w toku procesu kształcenia były rozwijane i konkretyzowane przez nauczycieli (por. Konarzewski, 2004). Burzliwe dyskusje dotyczące tego dokumentu w większym stopniu są jednak efektem częstotliwości wprowadzanych w podstawach zmian, jak i samej organizacji i przebiegu prac nad nimi (w tym doboru specjalistów).

Najnowsze podstawy programowe (a w zasadzie tylko ich część) zostały uchwalone 14 lutego 2017 roku. Niestety, ciągle panuje przekonanie, iż wiele uwag, jakie pojawiły się w kontekście podstaw programowych ze strony środowiska naukowego, dotyczących proponowanych wtedy jeszcze zapisów, nie zostało w podstawie uwzględnionych. Do dziś bowiem władze oświatowe nie zdradzają, w jaki sposób dobierane są treści do realizacji w polskich szkołach, nie znamy też klucza ich weryfikacji i zmian (Śliwerski, 2015). Treści kształcenia, wypełniające plany i programy szkolne, to tylko jeden $\mathrm{z}$ wielu problemów - „kamieni milowych” w tak dawno rozpoczętym już procesie dążenia do nowej i nowoczesnej szkoły (Kupisiewicz, 2010). Jak się okazuje, współczesna edukacja w kwestii nowoczesności nie spełnia wielu oczekiwań, a jej kondycja wciąż kojarzona jest raczej z poważnym kryzysem instytucji „(...) utworzonych na potrzeby innej rzeczywistości” (Bauman, 2007, s. 143). Jeśli jednak jedną z najbardziej istotnych cech współczesnego życia społecznego i gospodarczego jest wciąż wzrastająca wartość wiedzy, to procesy demokratyzacji życia społecznego, z widocznym wyzwalaniem się narodów i grup etnicznych, stają się symbolem upodmiotowienia jednostek i grup społecznych, zwiększaniem ich niezależności, samodzielności i odpowiedzialności.

Życie w takiej rzeczywistości wymaga od nas znacznie większej wiedzy, kwalifikacji i kompetencji. Edukacja i wykształcenie ludzi decyduje o jakości systemów demokratycznych, ich „odporności” na dewiacje i wypaczenia, które mogą zburzyć nawet najlepiej zapowiadające się projekty reform społecznych (Szymański, 2008, ss. 5-19). W naszym kraju edukacja wciąż stanowi element kontrowersji ideologicznych i walki politycznej, wciąż jest narzędziem w ręku elit władzy i polityków. Jak wiadomo, „(...) zmiany układu sił politycznych znajdują odbicie w treściach kształcenia i wychowania, w lansowanych ideach, w ocenach historycznych i współczesnych faktów, zjawisk i procesów. Radykalne zmiany treści kształcenia, zmiana lektur szkolnych, wizja edukacji wpisanej w pomysł patriotyzmu historycznego - zmieniają obraz historii, bardzo często zniekształcają ten obraz (w imię rugowania innego fałszywego obrazu), wykreślają z historii lub deprecjonują długie i ważne okresy dziejów Polski i Polaków" (Lewowicki, 2008, s. 24). Dlatego nie można dziś myśleć o treściach kształcenia w kategoriach, do których przywykliśmy. 
O zakresie i dynamice przemian treści w edukacji wciąż decyduje wiele czynników, do których zalicza się oczywiście wzrost roli nauki, ale i rozwój środków masowego przekazu, zwiększanie zasobów czasu wolnego (Denek, 2011). A przecież już na początku lat 90. ubiegłego wieku podobne postulaty przekonywały nas o konieczności gruntownej reformy systemu oświaty. Przypomnijmy, iż w uzasadnieniach tej ważnej reformy podkreślano poprawę jakości edukacji, wyrównanie szans edukacyjnych, ale i dokonanie zdecydowanych zmian w treściach kształcenia (Bogaj, Kwiatkowski i Piwowarski, 2001). W przygotowanym wówczas projekcie reformy wyraźnie zalecono więc „usunięcie ze szkolnych programów nadmiaru wiadomości encyklopedycznych i skoncentrowanie uwagi szkoły na rozwijaniu samodzielnego myślenia uczniów (...) ustanowienie rzeczywistej autonomii programowej szkół" (Ministerstwo Edukacji Narodowej, 1998). Niestety, do dziś wielu z tych zaleceń nie udało się zrealizować. I dotyczy to również edukacji regionalnej i międzykulturowej. Przemiany w tak wielu dziedzinach naszego życia dowodzą, iż treści z tego obszaru są w dzisiejszej szkole niezbędne.

\section{Od edukacji regionalnej do międzykulturowej - koncepcja kształtowania tożsamości międzykulturowej w ujęciu Jerzego Nikitorowicza}

Zmiany systemowe w Polsce, procesy integracji europejskiej, ale i nowe oblicza samych narodów, grup etnicznych i społeczności lokalnych, już przed wieloma laty wywołały w Polsce poważne dyskusje. To spowodowało, iż dość popularne (również w badaniach naukowych) stały się pojęcia takie jak tożsamość, ojczyzna, region, dziedzictwo kulturowe. Edukacja regionalna, choć należy do dość młodych koncepcji, ma bogate naukowe korzenie (Petrykowski, 2003).

Jedną z pierwszych publikacji oświatowych, w której określone zostały jej cele i zadania, jest dokument wydany w październiku 1995 roku pt. Dziedzictwo kulturowe w regionie. Założenia programowe, gdzie czytamy: „Celem edukacji regionalnej w procesie dydaktyczno-wychowawczym jest ukształtowanie w uczniach poczucia własnej tożsamości regionalnej jako postawy zaangażowania się w funkcjonowanie własnego środowiska i autentycznego otwarcia się na inne społeczności i kultury" (Ministerstwo Edukacji Narodowej, 1995, s. 3). Wśród pozostałych celów wymienia się: 1) zapoznanie ucznia $\mathrm{z}$ wiedzą o własnym regonie w powiązaniu z rzeczywistością narodową, państwową i międzynarodową w płaszczyźnie geograficznej, etnograficznej, jak 
i kulturowej, 2) uświadomienie wartości regionu w kontekście wartości narodowych, państwowych i ogólnoludzkich, 3) wprowadzenie ucznia w świat wartości środowiska, 4) kształtowanie tożsamości pluralistycznej, której istota polega na tym, iż człowiek poznając własną społeczność i kulturę, „uczy się trafniej odczytywać i interpretować zachowanie innych, uczy się szanować ich odmienność" (Ministerstwo Edukacji Narodowej, 1995, s. 4).

Edukacja regionalna, stanowiąca swoisty powrót do źródeł życia każdego człowieka (Kossak-Główczewski, 1993), odgrywa również bardzo ważną rolę w odkrywaniu przeszłości regionu (Sacharczuk i Szwarc, 2019, ss. 248-267). Ułatwia kształtowanie i utrwalanie postaw regionalnych wśród dzieci i młodzieży. Bardzo ważną swoistością edukacji regionalnej jest również to, iż stwarza szanse na doświadczanie kontaktów z odmiennością, wspomaga proces kształtowania umiejętności współżycia z innymi, dzięki czemu umożliwia przetrwanie wartości małej ojczyzny (Sobecki, 2007).

Edukacja międzykulturowa natomiast postrzegana jest jako „ogół wzajemnych wpływów i oddziaływań jednostek i grup, instytucji, organizacji, stowarzyszeń, związków sprzyjających takiemu rozwojowi człowieka, aby stawał się on w pełni świadomym i twórczym członkiem wspólnoty rodzinnej, lokalnej, regionalnej, wyznaniowej, narodowej, kontynentalnej, kulturowej, globalnej - planetarnej oraz był zdolny do aktywnej samorealizacji, kształtowania trwałej tożsamości i odrębności” (Nikitorowicz, 2009, s. 282). Edukacja międzykulturowa jest nową subdyscypliną edukacyjną, która intensywnie zaczęła rozwijać się w Polsce w latach 90. Warto również podkreślić, iż powodzenie edukacyjne tej koncepcji naukowej uzależnione jest od wielu czynników, takich jak doświadczenia historyczne, poziom rozwoju społeczeństw, ale i funkcjonowanie systemu społeczno-politycznego (Ogrodzka-Mazur, 2018, ss. 65-82). Niezbędne jest w tym również wsparcie ze strony władz samorządowych i lokalno-państwowych (Boski, 2010, s. 609).

W literaturze przedmiotu wskazuje się wiele klasyfikacji i ujęć funkcji oraz celów edukacji międzykulturowej (Grzybowski, 2007; Lewowicki, 2015, ss. 24-33; Sobecki, 2016). Do najważniejszych z nich należy „przygotowanie jednostki do funkcjonowania w warunkach zróżnicowania kulturowego (...) ukształtowanie właściwych postaw wobec odmienności kulturowej zbudowanych na bazie samoakceptacji i zakorzenienia" (Sobecki, 2007, ss. 34-35) oraz „uczenie się budowania pozytywnych relacji z drugim człowiekiem i uświadamianie sobie różnic i podobieństw pomiędzy ludźmi" (Szczurek-Boruta, 2006, s. 37). Współcześnie realizacja powyższych założeń nie wzbudza wątpliwości, jest konieczna z uwagi stan pogłębiającego się zróżnicowania kultu- 
rowego współczesnych społeczeństw. To właśnie edukacja ma do odegrania bardzo ważną rolę w procesie zapoznania z tą różnorodnością, przy jednoczesnym zachowaniu wartości i odrębności własnej kultury (Nikitorowicz, 2005a, ss. 15-33; 2020).

Istotnym założeniem koncepcji kształtowania tożsamości międzykulturowej jest konieczność posiadania przez człowieka takich cech, które pozwalają na posiadanie świadomości odrębności, ale i podobieństwa do innych. Bardzo ważny jest tu sam przebieg kształtowania tożsamości, przede wszystkim identyfikacja z kulturą rodzimą, a więc „(...)świadomość poczucia zakorzenienia i wartości rdzennych, świadomość czasu, przestrzeni, trwania i przemijania oraz związana z tym świadomość znaczenia i wagi przeszłości, wspólnych losów, przejść i wszystkich zdarzeń zatrzymanych w pamięci zbiorowej oraz świadomość teraźniejszości i poczucia indywidualności, siły i mocy jednostkowej oraz perspektyw rozwoju indywidualnego i grupowego" (Nikitorowicz, 2005b, s. 93).

Wynika to z funkcjonowania człowieka w przestrzeni międzykulturowej, gdzie występuje problem wielu ojczyzn, problem zachowania własnej indywidualności w procesie kształtowania tożsamości osobowej i społecznej. Istota koncepcji tożsamości międzykulturowej „łączy to, co indywidualne, z tym, co społeczne, to, co rodzinne i lokalne, z tym, co globalne i uniwersalne" (Nikitorowicz, 2005b, s. 94). Wyjaśnia jednocześnie powiązania problematyki regionalnej i międzykulturowej w perspektywie obszaru zainteresowań edukacji międzykulturowej. Edukacja regionalna jest niezbędnym warunkiem powodzenia zamierzeń wynikających z teoretycznych założeń edukacji międzykulturowej. Zaznajamianie dzieci i młodzież z kulturą lokalną „rozpoczyna proces dialogu edukacyjnego, wzmacnia ich siły poprzez poznanie i zrozumienie siebie oraz swojej najbliższej kultury. W efekcie pozwala dostrzegać odmienności oraz poszukiwać sposobów wzajemnego zrozumienia, porozumienia i współpracy” (Nikitorowicz, 2017, s. 130). Dlatego „istotą procesu kształtowania tożsamości międzykulturowej jest nadanie wartości tożsamości przypisanej, niezamykanie jej, ale - na zasadzie uświadamianych wartości otwieranie na inne kultury" (Nikitorowicz, 2017, s. 398). I - co istotne - należy rozpocząć ten proces jak najwcześniej, już na etapie przedszkola. 


\section{Treści regionalne $\mathrm{i}$ wielokulturowe $\mathrm{w}$ podstawie programowej wychowania przedszkolnego i edukacji wczesnoszkolnej ${ }^{1}$}

Jak zostało zasygnalizowane na początku artykułu, jego celem jest zaprezentowanie treści dotyczących różnorodności kulturowej w podstawie programowej przedszkola i edukacji wczesnoszkolnej. Już w preambule podstawy dla przedszkoli czytamy, iż głównym celem wychowania na tym etapie jest wsparcie całościowego rozwoju dziecka, co ma m.in. umożliwić zdobywanie doświadczeń na drodze prowadzącej do prawdy, dobra i piękna.

Wśród wielu zadań, jakie stoją przed przedszkolem, wskazuje się na „Wzmacnianie poczucia wartości, indywidualność, oryginalność dziecka oraz potrzeby tworzenia relacji osobowych i uczestnictwa w grupie (...), współdziałanie z rodzicami, różnymi środowiskami, organizacjami i instytucjami, uznanymi przez rodziców za źródło istotnych wartości, na rzecz tworzenia warunków umożliwiających rozwój tożsamości dziecka, kreowanie, wspólne $\mathrm{z}$ wymienionymi podmiotami, sytuacji prowadzących do poznania przez dziecko wartości i norm społecznych, których źródłem jest rodzina, grupa w przedszkolu, inne dorosłe osoby" (Dz.U. 2017, poz. 356, Załącznik 1, ss. 2-3). Powyższe cele, odnoszące się raczej do kwestii ogólnospołecznych, uzupełnione są o dwa zapisy, które w większym stopniu odnoszą się do treści kulturowych.

Pierwszy z nich zobowiązuje przedszkole do organizowania takich zajęć (jednak wyłącznie w przypadku zaistniałej potrzeby), które umożliwiałyby dziecku poznawanie kultury i języka mniejszości narodowej lub etnicznej lub języka regionalnego - kaszubskiego ${ }^{2}$.

1 Na podstawie Rozporządzenia Ministra Edukacji Narodowej z dnia 14 lutego 2017 r. w sprawie podstawy programowej wychowania przedszkolnego oraz podstawy programowej kształcenia ogólnego dla szkoły podstawowej, w tym dla uczniów z niepełnosprawnością intelektualną w stopniu umiarkowanym lub znacznym, kształcenia ogólnego dla branżowej szkoły I stopnia, kształcenia ogólnego dla szkoły specjalnej przysposabiającej do pracy oraz kształcenia ogólnego dla szkoły policealnej, Dz.U. 2017, poz. 356.

2 Język kaszubski jest jedynym językiem regionalnym, uwzględnionym w podstawie programowej. Należy pogratulować autorom tych części podstawy zarówno koncepcji, jak i precyzji w stworzeniu bardzo dobrych fundamentów do nauczania i uczenia się tego języka - przede wszystkim w wymiarze kulturowym. 
Kolejny natomiast dotyczy realizacji edukacji sprzyjającej budowaniu zainteresowania dziecka językiem obcym nowożytnym, w tym chęci poznawania innych kultur. Powyższe cele powinny być realizowane w oparciu o treści określone za pomocą efektów (w podstawie nazwano je osiągnięciami dziecka). Zostały one podzielone są na cztery obszary: fizyczny, emocjonalny, społeczny i poznawczy. Zagadnień z obszaru edukacji regionalnej i międzykulturowej nie znajdziemy w osiągnięciach natury fizycznej. Wśród jedenastu, bardzo ogólnie określonych efektów dotyczących sfery emocjonalnej, można odszukać podstaw takiej edukacji w zasadzie w dwóch przypadkach. Dotyczą one następujących sformułowań: dziecko „dostrzega emocjonalną wartość otoczenia przyrodniczego jako źródła satysfakcji” oraz „szanuje emocje swoje i innych osób” (Dz.U. 2017, poz. 356, Załącznik nr 1, ss. 4-5).

Najwięcej treści natury kulturowej odnajdziemy w obszarze społecznym i poznawczym. I tak, do pierwszego z nich zliczyć można efekty dotyczące wyrażania szacunku wobec innych, odczuwania i wyjaśniania swojej przynależności do rodziny, narodu, grupy przedszkolnej i innych grup, wartości związanych z umiejętnościami i zachowaniami społecznymi (np. szacunek do dzieci i dorosłych, szacunek do ojczyzny), praw i obowiązków swoich oraz innych osób, komunikacji z dziećmi i osobami dorosłymi, oczekiwań społecznych wobec innego dziecka, grupy. Natomiast wśród zapisów należących do najobszerniejszego działu natury poznawczej wskazać można tylko kilka grup aktywności dziecka: obszaru muzycznego (np. wykonania lub rozpoznawania łatwych piosenek ludowych, hymnu przedszkola, charakterystycznych dla uroczystości narodowych, takich jak: hymn narodowy, potrzebnych do organizacji uroczystości, np. Dnia Babci i Dziadka), natury geograficzno-przestrzennej (znajomość nazwy swojego kraju i jego stolicy, znajomość symboli narodowych, takich jak: godło, flaga, hymn, zagadnień dotyczących Polski jako jednego z krajów Unii Europejskiej, wybranych symboli związanych z regionami Polski ukrytych w podaniach, przysłowiach, legendach, bajkach). Do aktywności takich zaliczyć można również znajomość najbliższego środowiska (np. rozumienie świata, zjawisk i rzeczy znajdujących się w bliskim otoczeniu, zawody wykonywane przez rodziców i osoby z najbliższego otoczenia).

Wiele kwestii kulturowych dotyczy dwóch ostatnich punktów obszaru poznawczego, odnoszą się one jednak wyłącznie do sytuacji, gdy w przedszkolu istnieje potrzeba realizacji zajęć w języku mniejszości narodowej lub etnicznej czy w języku regionalnym (kaszubskim). W tym pierwszym przypadku dotyczą one konkretnej wspólnoty narodowej, etnicznej, językowej, godła 
swojej wspólnoty narodowej, etnicznej, językowej i cech charakterystycznych regionalnego stroju ludowego. Natomiast dzieci, które w przedszkolu uczą się języka regionalnego - kaszubskiego, mają okazję poznać kaszubskie wyrazy i zwroty, obecne w podejmowanych zabawach i innych czynnościach (to powtarzanie rymowanek i prostych wierszyków, śpiewanie piosenek; rozumienie krótkich historyjek opowiadanych lub czytanych wspieranych np. obrazkiem, rekwizytem, gestem, jak i znajomość godła (symbolu) swojej wspólnoty regionalnej - kaszubskiej).

Niestety, również w części końcowej dokumentu, gdzie proponowane są warunki i sposoby realizacji procesu kształcenia, nie znajdujemy odniesień do kwestii kulturowych. Choć znajduje się tu wiele wskazówek metodyczno-organizacyjnych, związanych chociażby z kreowaniem przestrzeni rozwoju dzieci, w tym jej aranżacji (np. tworzenia stałych i czasowych kącików zainteresowań), w żadnym miejscu nie wspomina się o wykorzystaniu do tych celów, np. wartości i treści regionalnych czy - szerzej - kulturowych. Jedynym zapisem, który mógłby stać się inspiracją dla nauczycieli przedszkola w realizacji założeń edukacji regionalnej i międzykulturowej, jest propozycja, by włączać do zabaw i doświadczeń przedszkolnych potencjał tkwiący w dzieciach oraz ich zaciekawienie elementami otoczenia.

Podstawa programowa edukacji wczesnoszkolnej stanowi (wraz z kolejnym etapem edukacyjnym - klasami IV - VIII) kolejny załącznik do rozporządzenia (Dz.U. 2017, poz. 356, załącznik nr 2). Stąd kilkustronicowy wstęp dotyczący celów i zadań edukacji w szkole podstawowej odnosi się do procesu kształcenia realizowanego na tych dwóch etapach. Podkreśla się tu wartości patriotyzmu i szacunku dla tradycji, wzmacnianie poczucia tożsamości indywidualnej, kulturowej, narodowej, regionalnej i etnicznej, kształtowanie szacunku dla godności innych osób, jak i postaw otwartych wobec świata i innych ludzi, promowanie aktywności w życiu społecznym. Wśród rozwijanych umiejętności wskazuje się ponadto na aktywny udział w życiu kulturalnym szkoły, środowiska lokalnego oraz kraju. Jak czytamy: „kształcenie i wychowanie w szkole podstawowej sprzyja rozwijaniu postaw obywatelskich, patriotycznych i społecznych uczniów. Zadaniem szkoły jest wzmacnianie poczucia tożsamości narodowej, przywiązania do historii i tradycji narodowych, przygotowanie i zachęcanie do podejmowania działań na rzecz środowiska szkolnego i lokalnego, w tym do angażowania się w wolontariat. Szkoła dba o wychowanie dzieci i młodzieży w duchu akceptacji i szacunku dla drugiego człowieka, kształtuje postawę szacunku dla środowiska przyrodniczego (...)" (Dz.U. 2017, poz. 356, załącznik nr 2, s. 14). 
Natomiast już w części poświęconej edukacji wczesnoszkolnej, podkreśla się organizowanie zajęć umożliwiających poznanie wartości i norm społecznych, których źródłem jest rodzina, społeczność szkolna, społeczność lokalna i regionalna, naród. Wymienia się również konieczność kształtowania i rozwijania zachowań wynikających z tych wartości, wspierających poznawanie kultury narodowej, środowiska przyrodniczego, odbiór sztuki i potrzebę jej współtworzenia w zakresie adekwatnym do etapu rozwojowego dziecka, jak i umożliwiających zaspokojenie potrzeb poznawania kultur innych narodów, w tym krajów Unii Europejskiej, różnorodnych zjawisk przyrodniczych, sztuki, a także zabaw i zwyczajów dzieci innych narodowości (w tym krajów Unii Europejskiej), różnorodnych zjawisk przyrodniczych, sztuki, a także zabaw i zwyczajów dzieci innych narodowości.

Wskazuje się również na konieczność współdziałania z rodzicami, różnymi środowiskami, organizacjami i instytucjami, uznanymi przez rodziców za źródło istotnych wartości, na rzecz tworzenia warunków umożliwiających rozwój tożsamości dziecka. Natomiast cele kształcenia realizowane na etapie edukacji wczesnoszkolnej - podobnie jak na poziomie przedszkola - odnoszą się również do czterech „obszarów rozwojowych dziecka”. Choć odniesień interesujących mnie treści tu również nie zawiera dziedzina fizyczna, jednak w dziedzinie emocjonalnej pojawia się ich zdecydowanie więcej niż na etapie przedszkola. Dotyczy tego zapis następujących umiejętności/zachowań ucznia: rozpoznawania, rozumienia i nazywania emocji oraz uczuć swoich, jak i innych osób, tworzenia relacji oraz umiejętność odczuwania więzi uczuciowej i potrzeba jej budowania (chodzi o więzi z rodziną, społecznością szkoły i wspólnotą narodową).

Podobna sytuacja dotyczy obszaru społecznego, w którym wskazuje się na kształtowanie świadomości wartości uznanych przez środowisko domowe, szkolne, lokalne i narodowe, potrzebę aktywności społecznej opartej o te wartości, na umiejętność nazywania poznanych wartości, oceny postępowania innych ludzi, odwoływania się w ocenie do przyjętych zasad i wartości, potrzebę i umiejętność identyfikowania się z grupami społecznymi, które dziecko reprezentuje, nazywania tych grup i ich charakterystycznych cech, umiejętność tworzenia relacji, współdziałania, współpracy, czy umiejętność samodzielnego wyrażania swoich oczekiwań i potrzeb społecznych. Natomiast w obszarze poznawczym podkreśla się umiejętność rozumienia legend, faktów historycznych, tradycji, elementów kultury materialnej i duchowej oraz pojęć i symboli z nimi związanych, takich jak: rodzina, dom, naród, ojczyzna, kraj, umiejętność uczestnictwa w kulturze oraz wyrażania swych 
spostrzeżeń i przeżyć za pomocą plastycznych, muzycznych i technicznych środków wyrazu, a także przy użyciu nowoczesnych technologii oraz umiejętność samodzielnej eksploracji świata.

Powyższe umiejętności uszczegółowiono w kolejnej części podstawy zatytułowanej „Treści nauczania ${ }^{3}$ - wymagania szczegółowe”, i przyporządkowano "poszczególnym dyscyplinom naukowym” (co w obu wypadkach określono dość niefortunnie). Wśród trzynastu obszarów edukacyjnych na szczególną uwagę zasługuje edukacja społeczna, w której zaakcentowana została problematyka identyfikacji z różnymi grupami społecznymi, głównie w zakresie ich rozpoznawania i opisywania (to m.in. rodzina, klasa w szkole, drużyna sportowa, społeczność lokalna, naród, ale i zespoły artystyczne, a także inne narodowości). Zalicza się do nich również znajomość ciekawostek historycznych dotyczących regionu, kraju, ale i uczestnictwo w wyborach samorządu uczniowskiego, znajomość przykładów powstałych w efekcie porozumień i umów grup społecznych (np. stowarzyszenia pomocy chorym i niepełnosprawnym dzieciom, organizacje ekologiczne, a także stowarzyszenia dużych grup społecznych, jak miasta i państwa czy Unia Europejska), znajomość i poszanowanie zwyczajów i tradycji różnych grup społecznych i narodów, zwyczajów ludzi (np. dotyczących świąt w różnych regionach Polski, ale i w różnych krajach).

Wiele z nich odnosi się do zakresu orientacji w czasie historycznym (np. powstanie państwa polskiego, legendy z powstaniem godła i barw narodowych, legendy dotyczące regionu), ale i do tematów dotyczących symboli narodowych, wybranych regionalnych strojów ludowych, świąt narodowych i innych ważnych dni pamięci narodowej, patrona szkoły, miejscowości, problematyki kraju. Natomiast w edukacji przyrodniczej efekty uczenia się dotyczą tematów związanych z krajem, miejscowością i regionem w kontekście miejsc charakterystycznych z punktu widzenia bogactwa przyrody i przestrzeni geograficznej. Co zaskakujące, niewiele treści kulturowych odnaleźć można w obszarze edukacji muzycznej. Sformułowane efekty uczenia się w dziedzinie muzyki zawierają dość ogólne wskazania, a odnoszą się do śpiewania - nucenia (m.in. melodii dotyczących świąt, w tym świąt narodo-

3 Już w latach 90. XX wieku W. Okoń przekonywał, iż takie określenia wyrażają ideę dawnej pedagogiki „bez dziecka”, por. Okoń, W. 1996. Nowy słownik pedagogiczny. Warszawa: Wydawnictwo Akademickie „Żak”. Proponuje się więc w miejsce „nauczania” stosować określenie „kształcenia”, które wyznacza w realizacji procesu kształcenia czynności dwustronne: uczniów i nauczycieli - dotyczy to zarówno treści, jak i innych elementów procesu kształcenia (celów, metod itd.). 
wych, związanych z tradycjami i zwyczajami polskimi, czy śpiewania pieśni patriotycznych i historycznych, hymnu polskiego, „wybranych krótkich piosenek w języku obcym”) oraz wybranych tańców „integracyjnych, ludowych polskich oraz innych krajów Europy i świata” (Dz.U. 2017, poz. 356, załącznik nr 2, s. 45).

W obszarze edukacji językowej, na który składają się trzy odrębne punkty, odnaleźć możemy kolejne przykłady odniesień do treści regionalnych, jak i wielokulturowych. W przypadku realizacji języka obcego nowożytnego (co dotyczy wszystkich uczniów na etapie edukacji wczesnoszkolnej) efekty uczenia się koncentrują się wokół zagadnień dotyczących domu, szkoły, miejscowości i ogólnej wiedzy o innych krajach posługujących się danym językiem obcym. Podobnie, jak w przypadku przedszkola, zdecydowanie więcej treści kulturowych dotyczy zajęć, które kierowane są do dzieci uczących się języka mniejszości narodowej lub etnicznej. Tu efekty korespondują z tematyką własnego dziedzictwa narodowego lub etnicznego, historii, języka, tożsamości, elementów przyrody, kultury materialnej i duchowej. W tej części podstawy programowej również zdecydowanie staranniej opracowana została tematyka uczenia się języka regionalnego - kaszubskiego. Efekty skupiają się na samym uczniu, dotyczą „najbliższego otoczenia i przeżywanej codzienności”, bliskich, rodziny, domu, szkoły, przyrody, Kaszub jako środowiska lokalnego, świąt i tradycji wraz z jej elementami. Wśród treści pojawia się ponadto zagadnienie edukacji międzykulturowej (w zakresie różnic pomiędzy polskimi a kaszubskimi tradycjami). Warto podkreślić, iż wiele efektów odnoszących się do poszczególnych aktywności ucznia zostało opatrzonych tu dodatkowymi szczegółami i ważnymi wskazówkami (np. co do sposobu ich realizacji czy propozycji wykorzystania określonych środków dydaktycznych).

Ostatni punkt w realizacji zajęć na etapie edukacji wczesnoszkolnej stanowi etyka. Wiele uwagi skoncentrowano tu na samym pojęciu etyki, zagadnieniu godności i wolności, relacji z innymi ludźmi, szacunku, wspólnot ludzkich oraz wartości. Niestety, treści odnoszących się do edukacji regionalnej i międzykulturowej w zasadzie brak jest w edukacji polonistycznej, nie znajdziemy ich również w pozostałych obszarach - edukacji matematycznej, plastycznej, technicznej, informatycznej czy w wychowaniu fizycznym. Należy zatem mieć nadzieję, iż zostały one umieszczone w przepisach dotyczących realizacji wyżej wymienionych przedmiotów na kolejnym już etapie edukacyjnym. 


\section{Zakończenie}

Edukacja ma do spełnienia bardzo ważne kulturowe zadania. Czy jednak współczesna oświata już od najmłodszych lat przygotowuje do uczestnictwa w kulturze? Na ile uczy współtworzenia własnej kultury i kształtuje postawy otwarte na odmienność kulturową, na ile inspiruje do kontaktów międzykulturowych? Odpowiedzi na powyższe pytania dostarczyć mogą tylko badania naukowe, prowadzone oczywiście na wszystkich etapach edukacyjnych.

W moim odczuciu określone w aktualnej podstawie programowej treści (między)kulturowe nie są wystarczające. Jednak praktyka edukacyjna, jak i prowadzone badania naukowe ${ }^{4}$ są świadectwem tego, iż realizacja takich treści w dużej mierze zależy od samych nauczycieli - ich doświadczeń, przygotowania i kompetencji. Bowiem rola nauczyciela, zwłaszcza nauczyciela pracującego w środowisku wielokulturowym, zarówno w kontekście kształtowania indywidualnej tożsamości przez uczniów, jak i budowania świadomości związanej z funkcjonowaniem w świecie zróżnicowanym kulturowo - jest ogromna. Kluczowe jest jednak, by rozpocząć taką edukację jak najwcześniej. By umożliwić każdemu dziecku tworzenie siebie, pozwolić na kształtowanie postaw odpowiedzialności i refleksji nad własnym działaniem i dokonywanymi wyborami (Ogrodzka-Mazur, 2007). Przegląd aktualnych podstaw programowych pierwszych etapów edukacyjnych dowodzi, iż (zwłaszcza na etapie przedszkola) niewiele jest odniesień do różnorodności kulturowej. Obecne zagadnienia dotyczą raczej podstawowej wiedzy z obszaru najbliższego otoczenia, postrzeganego bardziej w kategoriach jedno-, a nie wielo-kulturowych. Ponadto zauważyć należy, iż przyjęty w podstawie zapis osiągnięć dziecka i ucznia (dotyczy to bowiem obu etapów edukacyjnych) jest dość ogólny. Czy tak określone treści umożliwiają nauczycielom swobodę w ich doborze i realizacji? Czy wiążą się raczej z wyłącznym dążeniem do osiągnięcia zapisanych efektów? Te pytania wydają się dość istotne w kontekście tradycyjnego postrzegania treści kształcenia jako gotowego pakietu wiedzy do przekazania uczniowi. Bowiem, jak zauważa Dorota Klus-Stańska, współcześnie powinniśmy się w większym stopniu interesować „(...) nie tym, w jakim stopniu uczniowie przyswoili treści programowe, ale tym, jak myślą i rozumieją rzeczywistość i jej elementy, jak się w nią angażują i jakie prze-

4 Doskonałym przykładem prowadzonych od wielu lat badań na ten temat są publikacje pedagogów cieszyńskiego i białostockiego środowiska naukowego. 
widują miejsce dla siebie w procesach społecznego tworzenia prawomocnej wiedzy" (Klus-Stańska, 2010, ss. 344-345).

\section{Bibliografia}

Bauman, Z. 2007. Edukacja: wobec, wbrew i na rzecz ponowoczesności. W: Dudzikowa, M. i Czerepaniak-Walczak, M. red. Wychowanie. Pojęcia. Procesy. Konteksty. T. I. Gdańsk: GWP, ss. 139-154.

Bogaj, A., Kwiatkowski, S.M. i Piwowarski, R. 2001. Wskaźniki edukacyjne: Polska 2000. Warszawa: Instytut Badań Edukacyjnych.

Boski, P. 2010. Kulturowe ramy zachowań spotecznych. Warszawa: Wydawnictwo Naukowe PWN.

Denek, K. 2011. Edukacja pozalekcyjna i pozaszkolna. Poznań: Wydawnictwo Naukowe Wyższej Szkoły Pedagogiki i Administracji im. Mieszka I.

Grzybowski, P.P. 2007. Edukacja europejska - od wielokulturowośći ku międzykulturowości. Kraków: Oficyna Wydawnicza „Impuls”.

Klus-Stańska, D. 2010. Dydaktyka wobec chaosu pojęć i zdarzeń. Warszawa: Wydawnictwo Akademickie „Żak”.

Konarzewski, K. 2004. Reforma oświaty: podstawa programowa $i$ warunki ksztatcenia. Warszawa: Instytut Spraw Publicznych.

Kossak-Główczewski, K. 1993. Niektóre aspekty niezależnej edukacji regionalnej. W: Rodziewicz, E. i Szczepska-Pustkowska, M. red. Od pedagogiki ku pedagogii. Toruń: Wydawnictwo „Edytor”, ss. 66-84.

Kupisiewicz, C. 2010, Szkice z dziejów dydaktyki: od starożytności po czasy dzisiejsze. Kraków: Oficyna Wydawnicza „Impuls”.

Lewowicki, T. 2008. O szkodliwości współczesnego języka sfery publicznej. Annales Academiae Paedagogicae Cracoviensis. Studia Paedagogica. 1, ss. 20-25.

Lewowicki, T. 2015. Intercultural education - from assimilation to integrationand multidimensional identity. In: Kyuchukov, H., Lewowicki, T. and Ogrodzka-Mazur, E. eds. Intercultural education - concepts, practice, problems. Munich: LINCOM Academic Publishers, pp. 24-33.

Ministerstwo Edukacji Narodowej. 1995. Dziedzictwo kulturowe w regionie. Założenia programowe. Warszawa: Ministerstwo Edukacji Narodowej.

Ministerstwo Edukacji Narodowej. 1998. Reforma systemu edukacji. Projekt. Warszawa: Wydawnictwa Szkolne i Pedagogiczne.

Nikitorowicz, J. 2005a. Próba określania przedmiotu edukacji międzykulturowej. W: Nikitorowicz, J., Misiejuk, D. i Sobecki, M. red. Region. Tożsa- 
mość. Edukacja. Białystok: Wydawnictwo Uniwersyteckie „Trans Humana", ss. 15-33.

Nikitorowicz, J. 2005b. Kreowanie tożsamości dziecka. Wyzwania edukacji międzykulturowej. Gdańsk: GWP.

Nikitorowicz, J. 2009. Edukacja regionalna i międzykulturowa. Warszawa: WAiP.

Nikitorowicz, J. 2017. Etnopedagogika w kontekście wielokulturowości i ustawicznie kształtującej się tożsamości. Kraków: Oficyna Wydawnicza „Impuls”.

Nikitorowicz, J. 2020. Edukacja międzykulturowa w perspektywie paradygmatu wspótistnienia kultur. Białystok: Wydawnictwo Uniwersytetu w Białymstoku.

Ogrodzka-Mazur, E. 2007. Kompetencja aksjologiczna dzieci w młodszym wieku szkolnym. Studium porównawcze środowisk zróżnicowanych kulturowo. Katowice: UŚ.

Ogrodzka-Mazur, E. 2018. Intercultural education in Poland: current problems and research orientations. Kultura i Edukacja. 2, pp. 65-82.

Petrykowski, P. 2003. Edukacja regionalna. Problemy podstawowe i otwarte. Toruń: UMK.

Rozporządzenie Ministra Edukacji Narodowej z dnia 14 lutego 2017 r. w sprawie podstawy programowej wychowania przedszkolnego oraz podstawy programowej kształcenia ogólnego dla szkoły podstawowej, w tym dla uczniów z niepełnosprawnością intelektualną w stopniu umiarkowanym lub znacznym, kształcenia ogólnego dla branżowej szkoły I stopnia, kształcenia ogólnego dla szkoły specjalnej przysposabiającej do pracy oraz kształcenia ogólnego dla szkoły policealnej. Dz.U. 2017 poz. 356, Załącznik nr 1 i 2.

Sacharczuk, J. i Szwarc, A. 2019. Kultura regionu - inspiracje i kierunki rozwoju edukacji regionalnej. Kultura i Edukacja. 3, ss. 248-267.

Sobecki, M. 2007. Kultura symboliczna a tożsamość. Studium tożsamości kulturowej Polaków na Grodzieńszczyźnie z perspektywy edukacji międzykulturowej. Białystok: Wydawnictwo Uniwersyteckie „Trans Humana”.

Sobecki, M. 2016. Komunikacja międzykulturowa w perspektywie pedagogicznej. Studium z pogranicza polsko-litewsko-białorusko-ukraińskiego. Warszawa: Wydawnictwo Akademickie „Żak”.

Szczurek-Boruta, A. 2006. Tożsamość i jej szerszy kontekst instytucjonalny - o przydatności teorii strukturalizacji Anthony'ego Giddensa dla teorii i praktyki edukacji międzykulturowej. W: Lewowicki, T., Szczurek-Boruta, A. i Ogrodzka-Mazur, E. red. Teorie i modele badań międzykulturowych. Cieszyn - Toruń: UŚ, Wydawnictwo Adam Marszałek, ss. 31-40. 
Szymański, M. 2008. Problematyka edukacyjna we współczesnej debacie publicznej. Annales Academiae Paedagogicae Cracoviensis. Studia Paedagogica. 1, ss. 5-19.

Śliwerski, B. 2015. Edukacja (w) polityce. Polityka (w) edukacji. Inspiracje do badań polityki oświatowej. Kraków: Oficyna Wydawnicza „Impuls”.

\section{(Inter)cultural contents in the process of pre - and early school education - based on an analysis of the current core curricula}

Abstract: The aim of the article is to present the current core curriculum for kindergartens and early childhood education in the context of cultural diversity. Knowing your own local environment and the cultural canon of the region is an important element of intercultural education. The basis for the analyses of the core curricula are the assumptions of both regional and intercultural education. Tasks and goals, defined in the core curriculum, are presented to be achieved by modern kindergartens and schools. The learning outcomes that determine the content planned in the learning and teaching process were also analyzed. The theoretical basis for the considerations is the concept of intercultural identity by Jerzy Nikitorowicz.

Keywords: core curriculum, learning outcomes, content of educations, regional education, intercultural education 